\title{
An ethical decalogue for the reintroduction of species to urban habitats
}

\author{
Julián Monge-Nájera \\ Laboratorio de Ecología Urbana, Universidad Estatal a Distancia (UNED), 2050 San José, Costa Rica, julianmonge@gmail.com \\ Received 20-X-2017 • Corrected 07-XII-2017 • Accepted 12-XII-2017
}

\begin{abstract}
Reintroduction of species to their former habitats -after they have been built upon- will become more important as urbanization increases worldwide, but it should follow ethical guidelines. Here I propose ten guidelines that exclude species that threaten human life, health and property; protect organisms from significant suffering; provides them with proper habitat and assistance; includes experimental protocols, and is based on information gathered according to scientific standards.
\end{abstract}

Key words: ethical relationship with nature, cities as ecosystem, ecosystem restoration, humane treatment of organisms.

Efforts to reintroduce species to their former habitats, including areas now urbanized, are increasingly common and will become more important as urbanization grows worldwide in the next decades (Seddon, Armstrong \& Maloney, 2007; Barrientos, 2013).

Despite its laudable motives, reintroduction has costs and creates conflicts. Even simple plant reintroductions have failed, for example the Marsh Marigold, the Columbine and the Early Saxifrage (Drayton \& Primack, 2012). Some failures had a tremendous cost in suffering to the animals that researchers were trying to help (e.g. Wimberger, Downs \& Perrin, 2009), and in any case, it is impossible to fully revert to the original state (Barrientos, 2013).

Conflicts include reintroduced species that harm pets, crops or property. Damage can be direct, for example when animals eat stored food, or indirect, for example when they carry pathogens of pets or humans (Dickman, 2010). Some species have disappeared from urbanized
RESUMEN: Decálogo ético para la reintroducción de especies en hábitats urbanos. La reintroducción de especies a sus hábitats originales -tras haber edificado sobre ellas- será más importante a medida que la urbanización aumente en todo el mundo, pero debe seguir pautas éticas. Aquí propongo diez pautas, las cuales excluyen especies que amenacen la vida humana, la salud y la propiedad; protegen a los organismos del sufrimiento; les proporcionan hábitat y ayuda; incluyen protocolos experimentales y se fundamentan en información recopilada con rigor científico.

Palabras clave: relación ética con la naturaleza, ciudades como ecosistema, restauración de ecosistemas, tratamiento humanitario de los organismos.

areas as unintended collateral victims of urbanization, but others have been actively removed, and the careless reintroduction of animals that are lethal to humans is irresponsible (Wilson, 2004; Elliot-Hogg, 2014). Animals that were actively removed from areas inhabited by humans include fleas that transmit the Black Death (Haensch et al., 2010), and larger species like wolves, bears, lions, leopards, hyenas, pumas, coyotes and crocodiles.

Documented cases of predation include thousands of human victims, with women and children being particularly vulnerable (Treves \& Naughton-Treves, 1999; Löe \& Röskaff, 2004). Thus, reintroductions have positive and negative aspects and, as in any other human conflict, there is a need for ethical guidelines. To my knowledge, even though the IUCN published reintroduction procedures (IUCN, 2013) and Barrientos (2013) thoroughly detailed the requirements for habitat reconstruction, there are no specific clear and concise ethical guidelines for urban reintroductions. This article proposes ten, based on 
a review of scientific information about reintroduction attempts (see below).

Reintroductions can fail in the planning stage, during implementation and afterwards. For the planning stage, the IUCN procedures emphasize reintroduction only to the original range and only when the causes that led to extinction have disappeared; they also recommend monitoring and support during and after implementation (IUCN, 2013).

When deciding which species to reintroduce, only species that will not cause net damage to the ecosystem should be included, despite the extremist views for and against reintroduction (Elliot-Hogg, 2014).

Computer modeling has been found to be useful when assessing the outcome of optional introduction protocols and to select release places. For example, one attempt with butterflies failed because they could not reach the optimal microhabitat (Van Langevelde \& Wynhoff, 2009).

During the implementation stage, individuals that are stressed from capture and transportation, or that carry pathogens, may die or bring disease into the habitat (Vieira, Fonseca \& Rocha, 2015).

The establishment of reintroduction areas with proper experimental controls would allow better evaluation of results (Seddon et al., 2007). Field work should also identify and support any instances of natural re-colonization (Barrientos, 2013).

Monitoring, food supplementation, and veterinary assistance, are critical for the success of reintroductions, and should be kept afterwards (Vieira et al., 2015). For example, the rare damselfly Ischnura gemina was reintroduced to an urban park in California, but the population collapsed when vegetation changed (Hannon \& Hafernik, 2007).

Finally, stochastic phenomena can harm even well planned and implemented reintroductions, so reintroductions must be done in several places and repeated over several years until the populations become stable (Maschinski \& Duquesnel, 2007).

The scientific reports cited above are the bases for the following guidelines.

\section{GUIDELINES}

1. No predators capable of killing children will be reintroduced to urban areas.
2. There will be no introduction of species that significantly threaten human health, pets, crops or property.

3. Reintroduction will not be done when it implies significant suffering to the organisms being reintroduced, for example stress from capture or captivity.

4. Organisms that carry pathogens will not be reintroduced.

5. Organisms whose genes threaten the genetic pool of other organisms in the urban area will not be reintroduced.

6. Organisms will only be reintroduced when scientific data support a reasonable chance of long term survival (if funds are insufficient for the long term effort, reintroduction will not be attempted).

7. Reintroduced organisms will receive food supplementation and veterinary assistance as needed.

8. Reintroduction will be done in both experimental and control areas to produce reliable assessments (monitoring must continue afterwards to trigger interventions if necessary).

9. Reintroduction must be done in several places and repeated over several years to buffer for stochastic events.

10. People in the areas affected must participate in the decision process, and will receive education to make reintroduction sustainable (but final decisions must be based on objective information gathered according to scientific standards).

\section{ACKNOWLEDGEMENTS}

I thank Zaidett Barrientos and two anonymous reviewers for critical comments to an earlier version of this article.

\section{REFERENCES}

Barrientos, Z. (2013). ¿Cómo restaurar zonas verdes en ciudades tropicales? Ambientico, 232-233, 81-87.

Dickman, A. J. (2010). Complexities of conflict: the importance of considering social factors for effectively resolving human-wildlife conflict. Animal conservation, 13(5), 458466. doi: 10.1111/j.1469-1795.2010.00368.x

Drayton, B., \& Primack, R. B. (2012). Success rates for reintroductions of eight perennial plant species after 15 years. Restoration Ecology, 20(3), 299-303. doi: 10.1111/j.1526-100X.2011.00860.x 
Elliot-Hogg, E. (2014). A tale of two cities: coexisting with coyotes in an urban environment. Thesis. Lincoln, New Zealand: Lincoln University.

Haensch, S., Bianucci, R., Signoli, M., Rajerison, M., Schultz, M., Kacki, S., ... \& Carniel, E. (2010). Distinct clones of Yersinia pestis caused the black death. PLoS pathogens, 6(10), e1001134. doi: 10.1371/journal.ppat.1001134

Hannon, E. R., \& Hafernik, J. E. (2007). Reintroduction of the rare damselfly Ischnura gemina (Odonata: Coenagrionidae) into an urban California park. Journal of insect conservation, 11(2), 141-149.

IUCN (2013). Guidelines for Reintroductions and Other Conservation. Translocations. Gland, Switzerland: Species Survival Commission of the IUCN.

Löe, J., \& Röskaft, E. (2004). Large carnivores and human safety: a review. AMBIO: a journal of the human environment, 33(6), 283-288. doi: 10.1579/0044-7447-33.6.283

Maschinski, J., \& Duquesnel, J. (2007). Successful reintroductions of the endangered long-lived Sargent's cherry palm, Pseudophoenix sargentii, in the Florida Keys. Biological Conservation, 134(1), 122-129. doi: 10.1016/j. biocon.2006.07.012
Seddon, P. J., Armstrong, D. P., \& Maloney, R. F. (2007). Developing the science of reintroduction biology. Conservation biology, 21(2), 303-312. doi: 10.1111/j.1523-1739.2006.00627.x

Treves, A., \& Naughton-Treves, L. (1999). Risk and opportunity for humans coexisting with large carnivores. Journal of Human Evolution, 36(3), 275-282. doi: 10.1006/ jhev.1998.0268

Van Langevelde, F., \& Wynhoff, I. (2009). What limits the spread of two congeneric butterfly species after their reintroduction: quality or spatial arrangement of habitat? Animal Conservation, 12(6), 540-548.

Vieira, B. P., Fonseca, C., \& Rocha, R. G. (2015). Critical steps to ensure the successful reintroduction of the Eurasian red squirrel. Animal Biodiversity and Conservation, 38(1), 49-58.

Wilson, C. J. (2004). Could we live with reintroduced large carnivores in the UK?. Mammal Review, 34(3), 211-232. doi: 10.1111/j.1365-2907.2004.00038.x

Wimberger, K., Downs, C. T., \& Perrin, M. R. (2009). Two unsuccessful reintroduction attempts of rock hyraxes (Procavia capensis) into a reserve in the Kwa Zulu-Natal Province, South Africa. South African Journal of Wildlife Research, 39(2), 192-201. doi: 10.3957/056.039.0213

\section{EDITED BY CAROLINA SEAS}

